\title{
DESCRIPTION OF A NEW SPECIES OF GRAHAMISIA DELUCCHI FROM SRI LANKA AND KEY TO THE WORLD SPECIES (HYMENOPTERA: CHALCIDOIDEA: PTEROMALIDAE)
}

\author{
P.M. Sureshan ${ }^{1}$ and T.C. Narendran ${ }^{2}$ \\ ${ }^{1}$ Western Regional Station, Zoological Survey of India, Pune, Maharashtra 411044, India \\ 2 Department of Zoology, University of Calicut, Kerala 673635, India \\ Email: ${ }^{1}$ zsipune@mah.nic.in; ${ }^{2}$ drtcnarendran@yahoo.com
}

\begin{abstract}
A new species of Grahamisia, Pteromalidae (Diparinae) is described from Sri Lanka and its affinities with the related species are discussed. Key to the world species of Grahamisia is also provided.

KeYwords
Chalcidoidea, Diparinae, Grahamisia, Hymenoptera, Key,
new species, Pteromalidae, Sri Lanka.

AbBreviations

F1-F7 - Funicular segments first to seventh; MV - Marginal vein; OOL - Ocellocular distance; PMV - Post marginal vein; $P O L$ - Post ocellar distance; SMV - Sub marginal vein; STV - Stigmal vein; T1-T6 - Gastral tergites 1 to 6
\end{abstract}

\section{INTRODUCTION}

Grahamisia Delucchi belongs to the subfamily Diparinae of Pteromalidae, which is represented by seven species world over (Table 1). They are mainly distributed in the tropical regions of Africa, except for one species each described from China and India and an undetermined species from Sri Lanka (Hedqvist, 1969, Boucek et al, 1979, Narendran \& Mini, 2000, Xiao \& Huang, 1999). A new species is described here from Sri Lanka based on the collections deposited in the Bohart Museum of Entomology, University of California, which was made available for study to the first author on loan by the kind courtesy of Dr. Steven L. Heydon. A key to the world species of Grahamisia (modified from Narendran \& Mini, 2000) is also provided here.

\section{Grahamisia gastra sp. nov.}

(Figs. 1-2)

\section{Etymology}

Material examined

Holotype: Female, 10-14.vii.1999, Hantana Mt. $\left(07^{0} 15^{\prime} \mathrm{N} \&\right.$ $\left.80^{\circ} 37^{\prime} \mathrm{E}\right)$, Kandy Dist., Central province, Sri Lanka, coll. M\&J Warbauer (in Pan trap), Bohart Museum collection.

The species is named after the nature of gaster, which is oval and swollen.

\section{Diagnostic characters}

Female: Length 1.8-1.9mm (Holotype 1.9mm). Head brownishyellow with two brown bands on lower face, more brownish on upper third of face and vertex, three light brownish spots, one on lower part of scrobe and one each on either side of it (almost in the form of an incomplete band above the two lower brown bands); eyes silvery white; tip of mandibles brown; antennal scape whitish-yellow with a brown band on ventro basal part, pedicel and first five and base of fifth funicular segments pale brown, upper part of F6, F7 completely and club whitish-yellow.

Head: (including scrobe) Uniformly and moderately reticulate; clypeal area slightly raised, anterior margin straight, slightly wider than long; clypeal and paraclypeal area finely reticulated and with minute piliferous punctures, malar grooves distinct. Head in dorsal view $2.1 \mathrm{x}$ as wide as long; vertex with three pairs of dark brown setae; POL 1.2x OOL; genae weakly reticulate; malar space little shorter than half length of eye; eyes separated $0.9 \mathrm{x}$ their height, eye $1.4 \mathrm{x}$ as long as wide in profile; scrobe wide, not reaching median ocellus. Head in front view $1.13 \mathrm{x}$ as wide as long. Antennae inserted above lower margin of eyes, interantennal area slightly raised, toruli separated slightly more than their individual diameter, scape little shorter than eye, pedicel plus flagellum $1.4 \mathrm{x}$ as long as head width, pedicel slightly shorter than F1 and F2 combined; funicular segments slightly widening towards the tip; F1-F3 equal, F4-F6 slightly shorter than F3; F7 as long as F3, club three segmented, but sutures not distinct, as long as 3.5 preceding segments combined and $2.7 \mathrm{x}$ as long as wide.

Thorax: Yellowish-brown. Pronotum distinctly reticulate punctuate dorsally, lateral panel transversely striate. Mesoscutum 1.6x as wide as long, reticulate punctuate, reticulation stronger on median lobe than on sides, notauli meet in the middle, each scapula with a seta distally, black spot distinctly punctured. Scutellum medially $0.6 \mathrm{x}$ as long as mesoscutum, with 2 pairs of setae, frenal area longitudinally striate. Propodeum medially $0.82 \mathrm{x}$ as long as mesoscutum, finely reticulate without median carina, plicae on either side united above base of nucha to form of a ' $\mathrm{V}$ '-shaped structure with several small oblique longitudinal carinulae on either side. Prepectus smooth. Mesopleuron transversely striate except in subalar area smooth. Metapleuron smooth. Brachypterous, forewing stump just short of reaching base of petiole, as long as hind coxa, with a brown spot on the tip, with 4 strong brown setae (third one lost in the holotype, but present in the paratype), tegulae also with a short seta. Fore and hind coxae and basal part of hind femora whitish-yellow, remainder of legs yellowishbrown; hind coxae transversely striated dorsolaterally, $2 \mathrm{x}$ as long as broad. Relative lengths of hind coxa 11, femur 18, tibia 20 , tarsus 16 .

Gaster: Yellowish-brown dorsally except with an yellow transverse band covering hind part of $\mathrm{T} 1$ and base of $\mathrm{T} 2$, 

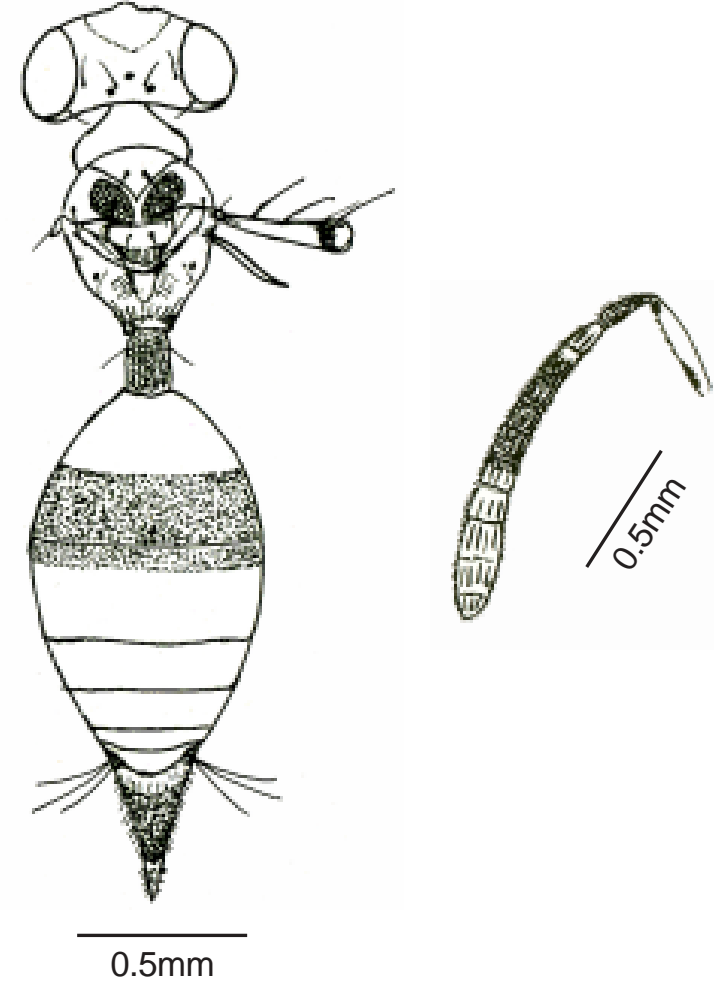

Figures 1-2. Grahamisia gastra sp. nov. (female). 1 - Body in dorsal view; 2 - Antenna.

epipygium except basal 1/5 and ventrolaterally almost yellow. Petiole longitudinally carinate, with reticulation between carinae, and with a pair of backwardly directed white setate anteriorly, $1.25 \mathrm{x}$ as long as wide. Gaster elongatedly ovate, in dorsal view $2.1 \mathrm{x}$ as long as wide and $1.5 \mathrm{x}$ as long as head plus thorax combined (without petiole), cerci long, epipygium finely reticulate and pubescent; ovipositor sheaths protruded out (in paratype, ovipositor strongly protruded out); hypopygium reaching upto tip of $\mathrm{T} 4$.

\section{Remarks}

The new species readily resembles G. maculata Hedqvist in general morphology especially in the shape of gaster and nature of propodeum. But it differs from maculata in having fore wing stumps with only four setae, antennae with club as long as 3.5 preceding segments combined, F7 completely and F6 partially whitish-yellow as on club, ocelli placed in a triangle with not very obtuse front angle, body brown with eyes silvery-white and mesonotum without bluish-metallic tint on elevated spots. (in maculata forewing stump with 7 long setae, antennae with club nearly as long as three preceding segments combined, F6 and F7 brown, ocelli placed in a triangle with very obtuse front angle and body yellow with black eyes and mesonotum with elevated spots that have a bluish-metallic tint).

Except for the swollen gaster and in the nature of propodeum it also resembles G. malabarensis Narendran \& Mini but differs from malabrensis as follows. In malabarensis the gaster is narrow and compressed with T3-T6 short, colour almost dark brown with epipygium and ventral part paler, forewing stump with three setae, propodeum with a weak median carina and plicae are not united above nucha to form a ' $\mathrm{V}$ '-shaped structure, antennae with F6 completely brown as on other funicular segments and size smaller $1.45-1.6 \mathrm{~mm}$. In the new species gaster is swollen with T3-T6 not very short and colour yellowish-brown with a distinct yellow band overlapping T1 and $\mathrm{T} 2$, forewing stump with four setae, propodeum with out indication of median carina and plicae united above nucha in the form of a ' $\mathrm{V}$ ' and antenna with F6 partly whitish-yellow as

Key to species of Grahamisia Delucchi (modified from Hedqvist, 1969; Narendran \& Mini, 2000) (for further figures see Hedqvist, 1969; Xiao \& Huang, 1999; Narendran \& Mini, 2000)

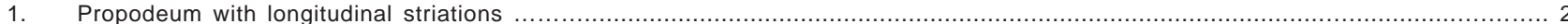

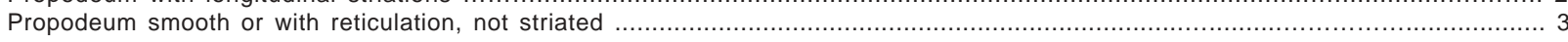

2. Head with rugose reticulation, all funicular segments brown, gaster with petiole as long as wide ..................................... G. striata Hedqvist Head with regular reticulation; F1-F4 yellowish; petiole longer than wide .................................................... dictyodroma Xiao \& Huang

3. Pronotum with a sharp transverse carina

G. albomaculata (Hedqvist)



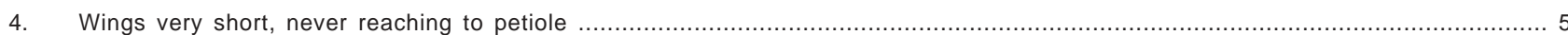

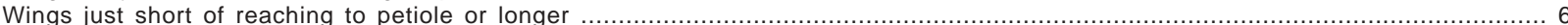

5. Scutellum with a black smooth area; gaster without two black setae anterior on T1

6. Forewing stump with seven setae; antennae with club nearly as long as combined length of three preceding segments; F6-F7 brown; ocelli in a triangle with very obtuse front angle ............................................................................ G. maculata (Hedqvist) Forewing stump with three or four strong setae ; club longer than combined length of three preceding segments; F7 and sometimes upper half of F6 whitish-yellow as on club; ocelli placed in a triangle with not very obtuse front angle

7. Gaster narrow and compressed with T3-T6 short, colour almost brown with epipygium and ventral part paler ; propodeum with a weak median carina and plicae not united above nucha to forma a 'V'-shaped structure ; antennae with F6 completely brown ; forewing stump with 3 setae; size, 1.45

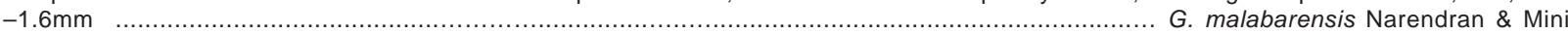
Gaster swollen (Fig.1) with T3-T6 not very short, colour yellowish-brown with a distinct yellow band overlapping T1 and T2 propodeum without median carina and plicae united in the form of 'V' above nucha ; F6 (Fig.2) partly whitish-yellow as on club; forewing stump with 4 setae; size 1.8$1.9 \mathrm{~mm}$.. 
Table 1. World species of Grahamisia Delucchi

\begin{tabular}{ll}
\hline Species & Distribution \\
\hline Grahamisia malabarensis Narendran \& Mini & India: Kerala \\
Grahamisia dictyodroma Xiao \& Huang & China: Hubei Province \\
Grahamisia albomaculata (Hedqvist) & W. Africa: Angola \\
Grahamisia saetosa Delucchi & Africa: Congo, Uganda, Tanzania \\
Grahamisia striata Hedqvist & S. Africa: Cape Prov., Sumerset \\
Grahamisia maculata (Hedqvist) & W. Africa: Angola \\
Grahamisia straminea Hedqvist & Central Africa: Congo. \\
\hline
\end{tabular}

on club and size larger, $1.8-1.9 \mathrm{~mm}$.

\section{REFERENCES}

Boucek, Z., B.R. Subba Rao and S.I. Farooqi (1979). A preliminary review of Pteromalidae (Hymenoptera) of India and adjacent countries. Oriental Insects 12(4): 433-468.

Hedqvist, K.J. (1969). New genera and species of Diparini with notes on tribe (Hymenoptera: Chalcidoidea). Entomol. Ts. Arg. 90(3-4): 174202.

Narendran, T.C. and T.V. Mini (2000). A key to species of Grahamisia Delucchi (Hymenoptera: Pteromalidae: Diparinae) with description of a new species from India. Zoos' Print Journal 15(12): 371-374.

Xiao, H. and D.W. Huang (1999). A new species of Grahamisia (Hymenoptera: Pteromalidae) from China. Oriental Insects 33: 333 336.

\section{ACKNOWLedGements}

The first author is grateful to Dr. J.R.B.Alfred, Director, Zoological Survey of India, Kolkatta and the Officer-in-charge, Zoological Survey of India, Western Regional Station, Pune and Western Ghats Field Research Station, Kozhikode for providing facilities and encouragement. We are also grateful to Dr. Steven L. Heydon, Bohart Museum, University of California, USA for providing the specimens for study on loan.

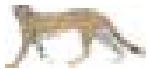

\section{VETBRIE}

ZOOS PRINT JOURNAL 19(9): 118

\section{POLYTHENE- BEZOAR IN BARKING DEER (MUNTIACUS MUNTJAK)}

\section{S.K. Mittal, A.B. Shrivastav and Pradeep Shrivastav}

Department of Wildlife Health and Management, College of Veterinary Science \& Animal Husbandry, Jawaharlal Nehru Krishi Vishwa Vidyalaya, Jabalpur, Madhya Pradesh

Bezoar means a concretion found in the alimentary canal of an animal, especially ruminants and occasionally man. According to the nature of constituents, there are various types of bezoar forming the ball like structure and known as trichobezoar (hairball), trichophytobezoar (hair \& vegetable fiber) and phytobezoar (plant fiber). A synthetic bezoar is known as polythene-bazoar. There are various types of bezoar observed in the gastrointestinal tract of different species of animals including wild herbivores (Rao \& Acharjyo, 1995; Sharma \& Chauhan, 1979).
An adult female Barking Deer Muntiacus muntjak of the Gwalior Zoo showed weakness of both hind legs with staggering gait. The deer was dewormed done soon after symptoms were observed and was given supportive treatment by injections of neurobion, calcium and tonophos along with adequate proteins, carbohydrates and minerals in the feed. The animal showed little improvement with little feed intake and defecation. After a week, the deer again showed weakness, staggering gait and dragging of both hind limbs. The animal was given a course of antibiotic with supportive treatment. The animal recovered to some extent but was unable to bear the body weight on her hind legs and soon died.

Detailed post-mortem examination of the carcass showed emaciation, ascitis, hydropericardium and oedema in throat region. The rumen was completely filled with a large mass of polythene-bezoar with knotted appearance. The bezoar consisted of entangled polythene bags, mineral deposits and ingested food. It was $34 \mathrm{~cm}$ in length and $278 \mathrm{~g}$ in weight. Impression smears prepared from liver, lungs and heart blood revealed no organism of pathological significance. The polythene-bezoar occupied substantial space in the rumen that had resulted in low intake of food for considerable time and may have led to deficiencies of essential vitamins and minerals and gradual increase in weakness and death of the animal.

Presence of foreign bodies in the fore stomach of deer is not uncommon (Acharjyo \& Nayak, 1979; Rao \& Acharjyo, 1995). Sharma and Chauhan (1979) reported the occurrence of phytozoar in the reticulum of a Barking Deer. The occurrence of polythene-bezoar was rare in wild herbivores but now their incidences are increasing particularly in captive animals due to the excessive use of polythene bags to carry food material and non-judicial discard of used bags with leftover food inside the enclosures by visitors.

\section{REFERENCES}

Acharjyo, L.N. and B.C. Nayak (199). Incidence of Trichobezoars in the two species of wild ruminants. Indian Veterinary Journal 56: 152

Rao, A.T. and L.N. Acharjyo (1995). Foreign Bodies in the animals and birds at Nandakanan Zoo. Indian Journal of Veterinary Pathology 19: $48-50$

Sharma, S.C. and R.S. Chauhan (1979). Phytobezoars in Barking Deer (Muntiacus muntjak). Indian Journal of Veterinary Pathology 21: 168-169.

\section{ACKNOWLEDGEMENT}

The author is thankful to Dr. D.S. Chauhan for help.

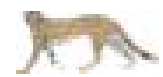

